Louisiana State University

LSU Digital Commons

$5-1-2009$

\title{
Cobaltacarborane-phthalocyanine conjugates: Syntheses and photophysical properties
}

\author{
Hairong Li \\ Louisiana State University \\ Frank R. Fronczek \\ Louisiana State University \\ M. Graça H. Vicente \\ Louisiana State University
}

Follow this and additional works at: https://digitalcommons.Isu.edu/chemistry_pubs

\section{Recommended Citation}

Li, H., Fronczek, F., \& Vicente, M. (2009). Cobaltacarborane-phthalocyanine conjugates: Syntheses and photophysical properties. Journal of Organometallic Chemistry, 694 (11), 1607-1611. https://doi.org/ 10.1016/j.jorganchem.2008.11.037

This Article is brought to you for free and open access by the Department of Chemistry at LSU Digital Commons. It has been accepted for inclusion in Faculty Publications by an authorized administrator of LSU Digital Commons. For more information, please contact ir@lsu.edu. 


\title{
Cobaltacarborane-phthalocyanine conjugates: Syntheses and photophysical properties
}

\author{
Hairong Li, Frank R. Fronczek, and M. Graça H. Vicente* \\ Department of Chemistry, Louisiana State University, 433 Choppin Hall, Baton Rouge, LA 70803, \\ USA
}

\begin{abstract}
Syntheses of two new cobaltacarborane-phthalocyanine conjugates, one anionic ( $\operatorname{Pc} 6)$ and one zwitterionic (Pc 7), were accomplished via cyclotetramerization of the corresponding cobaltacarborane-substituted phthalonitriles (4 or $\mathbf{5}$ ) with excess phthalonitrile in quinoline. X-ray structures of two phthalonitrile precursors ( 2 and $\mathbf{3}$ ) were obtained and are discussed, and the absorption and emission properties of the two cobaltacarborane-phthalocyanine conjugates in several solvents were investigated. The anionic conjugate $\mathbf{6}$ exists mainly as a monomer in polar organic solvents and has fluorescence quantum yields in the region $0.2-0.3$. The zwitterionic conjugate 7 aggregates in solution and displays lower quantum yields $\sim 0.1$ in organic solvents.
\end{abstract}

\section{Keywords}

Cobaltacarborane; Phthalocyanine; BNCT; PDT

\section{Introduction}

Phthalocyanines (Pcs) containing boron-10 are attractive dual sensitizers for the photodynamic therapy (PDT) and the boron neutron capture therapy (BNCT) of tumors, due to their strong absorptions in the near-IR, their ability for generating singlet oxygen with high quantum yields and their tendency for selective accumulation within tumor tissues [1-4]. BNCT [5] and PDT [6] are localized cancer treatment modalities that involve the irradiation of sensitizerrich tumors with low energy neutrons (in BNCT) or light (in PDT). The use of a single drug for both the BNCT and PDT of cancer has several advantages, since a dual treatment approach might lead to increased therapeutic efficacy due to the targeting of different cellular components and/or mechanisms of tumor cell destruction. We have recently reported the synthesis of boroncontaining chlorins [7,8], tetrabenzoporphyrins [9] and phthalocyanines [10] for application as dual sensitizers in BNCT and PDT. Of these classes of compounds cobaltacarboranecontaining Pcs show the strongest near-IR absorptions ( $>670 \mathrm{~nm}$ ), which are able to utilize light having a deeper penetration power into most human tissues [11]. Several phthalocyaninebased molecules, for example AlPcS4 and Pc4, are currently undergoing clinical investigations for application in PDT [12]. On the other hand, only a few boron-containing phthalocyanines have been reported to date, because of their difficult syntheses and purification procedures. We have recently synthesized a series of anionic cobaltacarboranyl-phthalocyanines that show

(C) 2008 Elsevier B.V. All rights reserved.

*Corresponding author. vicente@1su.edu..

Appendix A. Supplementary material CCDC 699696 and 699697 contain the supplementary crystallographic data for 2 and 3. These data can be obtained free of charge from The Cambridge Crystallographic Data Centre via www.ccdc.cam.ac.uk/data_request/cif. Supplementary data associated with this article can be found, in the online version, at doi:10.1016/j.jorganchem.2008.11.037. 
high solubility and exist as monomers in polar organic solvents [10]. Herein we report the syntheses of two new cobaltacarborane-phthalocyanine conjugates, one anionic and the other zwitterionic, and compare their solubility and photophysical properties.

\section{Results and discussion}

The synthetic route to cobaltacarborane-phthalocyanine conjugates 6 and 7 involves the nucleophilic attack of zwitterionic 3,3'- $\mathrm{Co}\left(8-\mathrm{C}_{4} \mathrm{H}_{8} \mathrm{O}_{2}-1,2-\mathrm{C}_{2} \mathrm{~B}_{9} \mathrm{H}_{10}\right)\left(1^{\prime}, 2^{\prime}-\mathrm{C}_{2} \mathrm{~B}_{9} \mathrm{H}_{10}\right)$ [13] by phenoxyl or pyridyl substituents situated on phthalonitriles $\mathbf{2}$ and $\mathbf{3}$, followed by cyclotetramerization in the presence of excess phthalonitrile and zinc acetate (Scheme 1). The (4-hydroxyphenoxyl)phthalonitrile (2) was synthesized using two different methods: (1) by nucleophilic aromatic substitution of the nitro group of $\mathbf{1}$ followed by deprotection of the methoxy group using $\mathrm{BBr}_{3}$ (in 33\% overall yield), or (2) by direct nucleophilic substitution of 3 -nitrophthalonitrile (1) using hydroquinone in $22 \%$ yield. 3-Pyridyloxyphthalonitrile (3) was prepared in $74 \%$ yield from the reaction of 3-nitrophthalonitrile (1) and 3-hydroxypyridine. The molecular structures of phthalonitriles $\mathbf{2}$ and $\mathbf{3}$ are shown in Fig. 1 and the crystal data are presented in Table 1. All CN triple bond distances fall within the range 1.147(2)-1.151(2) A. The conformations of the two molecules are quite similar. The dihedral angle formed by the phthalonitrile ring and the phenol ring in $\mathbf{2}$ is $82.80(3)^{\circ}$, while the corresponding angle between the phthalonitrile and pyridine rings in 3 is $70.50(3)^{\circ}$. The phenolic $\mathrm{OH}$ group in $\mathbf{2}$ forms an essentially linear intermolecular $\mathrm{O}-\mathrm{H} \cdots \mathrm{N}$ hydrogen bond with nitrile $\mathrm{N} 1$, having $\mathrm{O} \cdots \mathrm{N}$ distance

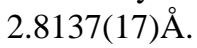

Cobaltacarborane-containing phthalonitriles 4 and $\mathbf{5}$ were synthesized in $94 \%$ yield via a nucleophilic opening reaction of the dioxane ring of 3,3'- $\mathrm{Co}\left(8-\mathrm{C}_{4} \mathrm{H}_{8} \mathrm{O}_{2}-1,2-\mathrm{C}_{2} \mathrm{~B}_{9} \mathrm{H}_{10}\right)\left(1^{\prime}, 2^{\prime}-\right.$ $\mathrm{C}_{2} \mathrm{~B}_{9} \mathrm{H}_{10}$ ) in the presence of anhydrous potassium carbonate, as previously reported [10]. Cyclotetramerization of phthalonitriles $\mathbf{4}$ and $\mathbf{5}$ with an excess (30 equiv.) of phthalonitrile in quinoline and in the presence of zinc acetate as template gave the target $\mathrm{A}_{3} \mathrm{~B}$-type phthalocyanines $\mathbf{6}$ and 7 in 8\% and 1\% yields, respectively. The very low yield obtained for Pc 7 is mainly due to the instability of pyridyloxyphthalonitrile (5) under the high temperature reaction conditions, and the lower solubility of Pc 7 in common organic solvents due to its higher tendency for aggregation compared with Pc 6. The observed low solubility of zwitterionic Pc 7 in comparison with anionic Pc 6, is in agreement with our earlier investigations of cobaltacarborane-porphyrin conjugates [14-16].

The ${ }^{1} \mathrm{H}$ NMR spectra of compounds $\mathbf{6}$ and $\mathbf{7}$ in deuterated DMF show the macrocycle protons on the three identical isoindole subunits in the downfield region between 8 and $10 \mathrm{ppm}$, consistent with those observed for the di-substituted analogs [10]. The aromatic protons on the phenoxyl and pyridyloxyl rings are shifted upfield to 7-8 ppm. The aliphatic and dicarbollide protons appear in the range 3-5 ppm. Mass spectrometry (ESI) shows the mono-negative molecular ion of Pc 6 at $\mathrm{m} / z$ 1095.4212 [M-K $]^{-}$. However, we were unable to obtain a clear mass spectrum with the expected isotopic patterns for Pc $\mathbf{7}$ due to its poor solubility in most organic solvents.

The absorption spectra of Pc 6 in acetone, DMF, DMSO and methanol show characteristic strong $Q$ bands typical of monomeric Pcs with extinction coefficients larger than $10^{5} \mathrm{~L}$ $\mathrm{mol}^{-1} \mathrm{~cm}^{-1}$. Fig. 2 shows the absorption spectrum of Pc 6 in various solvents. As we have previously observed [10], the $\lambda_{\max }$ for the $Q$ absorption band in DMSO (679 $\mathrm{nm}$ ) was redshifted by $7 \mathrm{~nm}$ compared with that in acetone $(672 \mathrm{~nm})$. In comparison with the anionic di$\alpha$-substituted cobaltacarboranyl-Pcs previously reported [10], Pc 6 shows 12-18 nm blueshifted absorption and emission bands. In HEPES pH 7.4 solution Pc $\mathbf{6}$ showed a significant broader and weaker absorption, indicating aggregation of this compound in aqueous solution. On the other hand, the zwitterionic Pc 7 shows broader, weaker and red-shifted $Q$ absorptions 
in acetone and DMSO compared with Pc 6, due to its higher tendency for aggregation. Pc 7 has a major absorption at $681 \mathrm{~nm}$ in acetone and a corresponding $14 \mathrm{~nm}$ red-shifted absorption in DMSO. In HEPES pH 7.4 solution Pc 7 showed even a broader and weaker absorption. The emission spectra of Pcs $\mathbf{6}$ and $\mathbf{7}$ in acetone and DMSO show the same trend as their absorption spectra, as seen in Fig. 3. The spectroscopic properties of Pc $\mathbf{6}$ and $\mathbf{7}$ are summarized in Table 2. While Pc 6 emits at $684 \mathrm{~nm}$ in DMSO Pc 7 emits at $701 \mathrm{~nm}$, a value similar to those observed for the anionic di- $\alpha$-substituted cobaltacarboranyl-Pcs [10]. However, Pc 7 shows decreased intensity of emission in acetone and DMSO compared with Pc 6. On the other hand Pc 6 has Stokes' shifts of 3-4 nm in polar organic solvents such as acetone, methanol and DMSO, while Pc 7 has larger Stokes' shifts of 8-10 nm in these solvents. Pc 6 has the largest fluorescence quantum yield [17] in DMSO (0.29), and the lowest in methanol (0.13). On the other hand Pc $\mathbf{6}$ has lower fluorescence quantum yields than Pc $\mathbf{7}$ in the corresponding solvent, the highest in DMSO and acetone (0.11), and the lowest in methanol (0.09). Quantum yields in the range 0.09-0.15 are typical for this type of compound $[10,18]$. Of all the cobaltacarborane-containing Pcs that we have tested to date, Pc $\mathbf{6}$ shows the largest fluorescence quantum yield in DMSO. We are currently investigating the biological properties of cobaltacarboranyl-Pcs, and their potential for application as dual sensitizers in the PDT and BNCT treatment of tumors.

\section{Conclusions}

Two new cobaltacarborane-phthalocyanine conjugates have been synthesized via the cyclotetramerization of the corresponding cobaltacarborane-phthalonitriles with excess phthalonitrile. The X-ray structures of phthalonitrile intermediates $\mathbf{2}$ and $\mathbf{3}$ are presented. While the anionic Pc $\mathbf{6}$ is highly soluble in polar organic solvents and only shows aggregation in aqueous solution, Pc 7 shows increased aggregation behavior in both polar organic solvents and in aqueous solution. Pc 6 has blue-shifted absorption and emission bands compared with di- $\alpha$-substituted cobaltacarboranyl-Pcs but significantly higher fluorescence quantum yields $(0.2-0.3)$ in polar organic solvents, while Pc 7 has decreased quantum yields of $\sim 0.1$. Both Pcs 6 and 7 might have application as dual sensitizers in the PDT and BNCT treatment of tumors.

\section{Experimental}

\subsection{General}

All reagents and solvents were purchased from commercial sources and used directly without further purification. Silica gel $60(230 \times 400$ mesh, Sorbent Technologies $)$ and alumina gel (50-200 $\mu \mathrm{m}$, neutral, standard activity I, Sorbent Technologies) were used for column chromatography. Analytical thin-layer chromatography (TLC) was carried out using polyester backed TLC plates 254 (precoated, $200 \mu \mathrm{m}$ ) from Sorbent Technologies. NMR spectra were recorded on a DPX-250 or AV-400 Bruker spectrometers $\left(250 \mathrm{MHz}\right.$ or $400 \mathrm{MHz}$ for ${ }^{1} \mathrm{H}, 63$ $\mathrm{MHz}$ or $100 \mathrm{MHz}$ for ${ }^{13} \mathrm{C}$ ). The chemical shifts are reported in $\delta \mathrm{ppm}$ using the following deuterated solvents as internal references: $\mathrm{CD}_{3} \mathrm{COCD}_{3} 2.04 \mathrm{ppm}\left({ }^{1} \mathrm{H}\right), 29.92 \mathrm{ppm}\left({ }^{13} \mathrm{C}\right) ; d$ DMF 2.92 ppm ( $\left.{ }^{1} \mathrm{H}\right), 34.89 \mathrm{ppm}\left({ }^{13} \mathrm{C}\right) ; \mathrm{CD}_{2} \mathrm{Cl}_{2} 5.32 \mathrm{ppm}\left({ }^{1} \mathrm{H}\right), 54.00 \mathrm{ppm}\left({ }^{13} \mathrm{C}\right) ; \mathrm{CDCl}_{3} 7.24$ ppm $\left({ }^{1} \mathrm{H}\right), 77.23 \mathrm{ppm}\left({ }^{13} \mathrm{C}\right)$. Electronic absorption spectra were measured on a Perkin-Elmer Lambda 35 UV-Vis spectrometer. MALDI-TOF mass spectra were recorded on a Bruker ProFlex III mass spectrometer using dithranol as the matrix, and high resolution ESI mass spectra were obtained on an Agilent Technologies 6210 Time-of-Flight LC/MS. HPLC purification was carried out on a Dionex system equipped with a P680 pump and a UVD340U detector with a multi-step gradient elution; $\mathrm{A}: \mathrm{H}_{2} \mathrm{O}$, B: acetonitrile; $85 \% \mathrm{~B}(0 \mathrm{~min})-95 \% \mathrm{~B}$ (10 $\mathrm{min})-100 \% \mathrm{~B}(20 \mathrm{~min})-100 \%$ B (37 min) 85\% B (40 min). A semi-preparative column Luna $\mathrm{C}_{18} 100 \AA, 5 \mu \mathrm{m}, 10 \times 250 \mathrm{~mm}$ from Phenomenex, USA, was used. 


\subsection{Phthalonitrile (2)}

4.2.1. Method A-3-Nitrophthalonitrile (1) $(1.5 \mathrm{~g}, 8.7 \mathrm{mmol})$ and 4-methoxyphenol (1.6 g, $12.9 \mathrm{mmol})$ were dissolved in dry DMF $(30 \mathrm{~mL})$. Potassium carbonate $(20 \mathrm{~g}, 14.5 \mathrm{mmol})$ was added in five portions. The reaction was heated at $90{ }^{\circ} \mathrm{C}$ for $2 \mathrm{~h}$. The reaction mixture was cooled to room temperature, poured into ice water $(500 \mathrm{~mL})$, and the resulting precipitate was collected. The crude product was purified by alumina column chromatography using dichloromethane for elution to afford a white solid $(1.8 \mathrm{~g}, 83 \%) .{ }^{1} \mathrm{H} \mathrm{NMR}\left(\mathrm{CDCl}_{3}, 250 \mathrm{MHz}\right)$ : $\delta 7.54(\mathrm{t}, J=8.2 \mathrm{~Hz}, 1 \mathrm{H}, \mathrm{Ar}-\mathrm{H}), 7.39$ (d, $J=7.6 \mathrm{~Hz}, 1 \mathrm{H}, \mathrm{Ar}-\mathrm{H}), 7.02-6.90(\mathrm{~m}, 5 \mathrm{H}, \mathrm{Ar}-\mathrm{H}), 3.80$ (s, 3H, Ar-H). ${ }^{13} \mathrm{C} \mathrm{NMR}\left(\mathrm{CDCl}_{3}, 63 \mathrm{MHz}\right): \delta 161.53,157.51,146.70,134.43,126.47,121.60$, $119.69,116.86,115.34,115.13,112.78,105.11(\mathrm{Ar}-\mathrm{C}, \mathrm{CN}), 55.59\left(\mathrm{OCH}_{3}\right)$. MS (MALDITOF) $m / z 250.934[\mathrm{M}+\mathrm{H}]^{+}$, calcd. for $\left[\mathrm{C}_{15} \mathrm{H}_{11} \mathrm{~N}_{2} \mathrm{O}_{2}\right] 251.082$. The methoxy-protected phthalonitrile $(1.0 \mathrm{~g}, 4 \mathrm{mmol})$ was dissolved in freshly distilled dichloromethane $(25 \mathrm{~mL})$ and the solution stirred at $-80{ }^{\circ} \mathrm{C}$. Boron tribromide $(0.4 \mathrm{~mL}, 4.2 \mathrm{mmol})$ in dichloromethane (10 $\mathrm{mL}$ ) was added drop-wise over $10 \mathrm{~min}$ via an addition funnel. The reaction solution was kept at $-80^{\circ} \mathrm{C}$ for $1 \mathrm{~h}$ and then stirred at room temperature for $24 \mathrm{~h}$. The reaction solution was slowly poured into $100 \mathrm{~mL}$ of ice water. The precipitate was collected, dissolved in $150 \mathrm{~mL}$ of ethyl acetate and extracted with $50 \mathrm{~mL}$ of $2 \mathrm{~N} \mathrm{NaOH}$ solution. After neutralization with 1 $\mathrm{N} \mathrm{HCl}$ and extraction with $150 \mathrm{~mL}$ ether, the organic layer was dried over anhydrous sodium sulfate. The crude product was purified by chromatography on a silica gel column using methanol/dichloromethane 1:9 for elution to afford a yellow solid $(0.4 \mathrm{~g}, 40 \%)$.

4.2.2. Method B-Hydroquinone $(1.0 \mathrm{~g}, 9 \mathrm{mmol})$ and potassium carbonate $(1.6 \mathrm{~g}, 11.6 \mathrm{mmol})$ were dissolved in anhydrous DMF $(30 \mathrm{~mL})$ under argon. The solution was heated to $50{ }^{\circ} \mathrm{C}$. 3Nitrophthalonitrile $(1 \mathrm{~g}, 5.8 \mathrm{mmol})$ dissolved in DMF $(2 \mathrm{~mL})$ was added via syringe. The reaction mixture was kept at $50^{\circ} \mathrm{C}$ for $2 \mathrm{~h}$ and stirred at room temperature for two days. After evaporation of the solvent under vacuum, $1 \mathrm{~N} \mathrm{HCl}(30 \mathrm{~mL})$ was added to the residue and the precipitate was filtered and washed with water. The precipitate was dissolved in acetone (50 $\mathrm{mL}$ ) and dried over anhydrous sodium sulfate. The crude product was purified by chromatography on a silica gel column using dichloromethane/methanol 95:5 for elution to afford a white solid $(0.3 \mathrm{~g}, 22 \%) .{ }^{1} \mathrm{H}$ NMR (acetone- $\left.d_{6}, 250 \mathrm{MHz}\right): \delta 8.75(\mathrm{br}, 1 \mathrm{H}, \mathrm{OH}), 7.79$ (t, $J=4.3 \mathrm{~Hz}, 1 \mathrm{H}, \mathrm{Ar}-\mathrm{H}), 7.68-7.65$ (m, 1H, Ar-H), 7.20-7.16 (m, 1H, Ar-H), 7.10-7.07 (m, $2 \mathrm{H}, \mathrm{Ar}-\mathrm{H}), 6.96-6.92(\mathrm{~m}, 2 \mathrm{H}, \mathrm{Ar}-\mathrm{H}) .{ }^{13} \mathrm{C}$ NMR (acetone- $\left.d_{6}, 63 \mathrm{MHz}\right): \delta 162.59,156.44$, $147.18,136.16,127.83,122.64,121.14,117.60,117.38,116.22,113.87,105.63$ (Ar-C, CN). HRMS-ESI $m / z$, $237.0655[\mathrm{M}+\mathrm{H}]^{+}$, calcd. for $\left[\mathrm{C}_{14} \mathrm{H}_{9} \mathrm{~N}_{2} \mathrm{O}_{2}\right]^{+} 237.0658$.

\subsection{Phthalonitrile (3)}

3-Nitrophthalonitrile (1) (1.5 g, $8.7 \mathrm{mmol})$ and 3-hydroxypyridine (1.5 g, $15.8 \mathrm{mmol})$ were dissolved in dry DMF ( $30 \mathrm{~mL})$. Potassium carbonate $(20 \mathrm{~g}, 14.5 \mathrm{mmol})$ was added to the solution in five portions. The reaction was heated at $90{ }^{\circ} \mathrm{C}$ for $4 \mathrm{~h}$. The mixture was cooled down to room temperature, poured into ice water $(500 \mathrm{~mL})$, and the resulting precipitate was collected. The crude product was purified by column chromatography on alumina using methanol/dichloromethane 5:95 for elution to afford a pink solid (1.4 g, 74\%). ${ }^{1} \mathrm{H}$ NMR $\left(\mathrm{CD}_{2} \mathrm{Cl}_{2}, 250 \mathrm{MHz}\right): \delta 8.54-8.48(\mathrm{~m}, 2 \mathrm{H}, \mathrm{Ar}-\mathrm{H}), 7.70-7.44(\mathrm{~m}, 4 \mathrm{H}, \mathrm{Ar}-\mathrm{H}), 7.15-7.12(\mathrm{~m}, 1 \mathrm{H}$, Ar-H). ${ }^{13} \mathrm{C}$ NMR $\left(\mathrm{CD}_{2} \mathrm{Cl}_{2}, 63 \mathrm{MHz}\right): \delta 160.16,151.10,147.58,142.71,135.29,128.30$, 127.86, 125.10, 121.16, 117.67, 115.43, 112.91, 106.84 (Ar-C, CN). MS (MALDI-TOF) $\mathrm{m} / \mathrm{z}$ $221.946[\mathrm{M}+\mathrm{H}]^{+}$, calcd. for $\left[\mathrm{C}_{13} \mathrm{H}_{8} \mathrm{~N}_{3} \mathrm{O}\right]^{+} 222.067$.

\subsection{Cobaltacarboranyl-phthalonitrile (4)}

A mixture of phthalonitrile (2) $(0.1 \mathrm{~g}, 0.41 \mathrm{mmol})$ and potassium carbonate $(61.5 \mathrm{mg}, 0.46$ $\mathrm{mmol})$ in acetone $(50 \mathrm{~mL})$ was refluxed at $50{ }^{\circ} \mathrm{C}$ under argon. After $20 \mathrm{~min}, 3,3^{\prime}-\mathrm{Co}(8-$ $\left.\mathrm{C}_{4} \mathrm{H}_{8} \mathrm{O}_{2}-1,2-\mathrm{C}_{2} \mathrm{~B}_{9} \mathrm{H}_{10}\right)\left(1^{\prime}, 2^{\prime}-\mathrm{C}_{2} \mathrm{~B}_{9} \mathrm{H}_{10}\right)(0.18 \mathrm{~g}, 0.43 \mathrm{mmol})$ [13] was added to the mixture in 
3 portions. The final mixture was heated for one day, then cooled to room temperature and the solvent removed under vacuum. The crude product was purified by silica gel chromatography using methanol/dichloromethane 5:95 for elution to afford a yellow solid $(0.24 \mathrm{~g}, 94 \%) .{ }^{1} \mathrm{H}$ NMR (acetone- $\left.d_{6}, 400 \mathrm{MHz}\right): \delta 7.81-7.77(\mathrm{~m}, 1 \mathrm{H}, \mathrm{Ar}-\mathrm{H}), 7.68-7.66(\mathrm{~m}, 1 \mathrm{H}, \mathrm{Ar}-\mathrm{H}), 7.22-$ 7.16 (m, 3H, Ar-H), 7.09-7.07 (m, 2H, Ar-H), 4.25 (br, 4H, OCH $), 4.16$ (t, J = 4.8 Hz, 2H, $\left.\mathrm{OCH}_{2}\right), 3.82\left(\mathrm{t}, J=4.8 \mathrm{~Hz}, 2 \mathrm{H}, \mathrm{OCH}_{2}\right), 3.59(\mathrm{~s}, 4 \mathrm{H}, \mathrm{CH}), 3.00-1.50(\mathrm{br}, 34 \mathrm{H}, \mathrm{BH}) .{ }^{13} \mathrm{C} \mathrm{NMR}$ (acetone- $\left.d_{6}, 100 \mathrm{MHz}\right): \delta 162.39,157.97,148.14,136.21,127.94,122.49,121.36,117.34$, 117.13, 116.20, 113.83, 105.72 (Ar-C, CN), 72.85, 70.12, 69.27, $68.98\left(\mathrm{OCH}_{2}\right), 55.15,47.22$ (CH). HRMS-ESI $m / z 646.3819[\mathrm{M}-\mathrm{K}]^{-}$, calcd. for $\left[\mathrm{C}_{22} \mathrm{H}_{36} \mathrm{~B}_{18} \mathrm{CoN}_{2} \mathrm{O}_{4}\right]^{-} 646.3812$.

\subsection{Cobaltacarboranyl-phthalonitrile (5)}

A mixture of phthalonitrile $(3)(0.1 \mathrm{~g}, 0.45 \mathrm{mmol})$ in acetone $(50 \mathrm{~mL})$ was refluxed at $50{ }^{\circ} \mathrm{C}$ under argon. 3,3'- $\mathrm{Co}\left(8-\mathrm{C}_{4} \mathrm{H}_{8} \mathrm{O}_{2}-1,2-\mathrm{C}_{2} \mathrm{~B}_{9} \mathrm{H}_{10}\right)\left(1^{\prime}, 2^{\prime}-\mathrm{C}_{2} \mathrm{~B}_{9} \mathrm{H}_{10}\right)[13](0.2 \mathrm{~g}, 0.48 \mathrm{mmol})$ was added to the reaction solution in 3 portions. The reaction mixture was heated for one day, then cooled to room temperature and the solvent removed under vacuum. The crude product was purified by silica gel chromatography using methanol/dichloromethane 5:95 for elution to afford the title compound as a yellow solid $(0.3 \mathrm{~g}, 94 \%)$. ${ }^{1} \mathrm{H}$ NMR (acetone- $d_{6}, 250 \mathrm{MHz}$ ): $\delta$ 9.34-9.28 (m, 2H, Ar-H), 8.69-8.66 (m, 1H, Ar-H), 8.35-8.29 (m, 1H, Ar-H), 8.05-7.96 (m, 2H, Ar-H), 7.83-7.79 (m, 1H, Ar-H), 5.01 (t, $\left.J=4.4 \mathrm{~Hz}, \mathrm{OCH}_{2}\right), 4.13-4.06\left(\mathrm{~m}, 4 \mathrm{H}, \mathrm{OCH}_{2}\right)$, $3.94\left(\mathrm{br}, 2 \mathrm{H}, \mathrm{OCH}_{2}\right), 3.64(\mathrm{~s}, 4 \mathrm{H}, \mathrm{CH}), 3.00-1.50(\mathrm{br}, 17 \mathrm{H}, \mathrm{BH}) .{ }^{13} \mathrm{C}$ NMR (acetone- $d_{6}, 63$ MHz): $\delta 158.15,155.06,143.84,138.80,137.03,131.24,130.21,124.39,118.17,115.76$, 113.03, 108.84 (Ar-C, CN), 73.32, 69.75, 69.70, 63.08, 52.73, $47.35\left(\mathrm{OCH}_{2}, \mathrm{CH}\right)$. HRMS-ESI $\mathrm{m} / \mathrm{z} 631.3981[\mathrm{M}-\mathrm{H}]^{-}$, calcd. for $\left[\mathrm{C}_{21} \mathrm{H}_{36} \mathrm{~B}_{18} \mathrm{CoN}_{3} \mathrm{O}_{3}\right]^{-} 631.3815$.

\subsection{Cobaltacarboranyl-phthalocyanine (6)}

Phthalonitrile (1.52 g, $12.0 \mathrm{mmol})$, anhydrous zinc(II) acetate $(0.4 \mathrm{~g}, 2.0 \mathrm{mmol})$ and phthalonitrile (4) $(67 \mathrm{mg}, 0.1 \mathrm{mmol})$ were added to a $10 \mathrm{~mL}$ thick-wall Schlenk tube. The tube was dried by purge-and-refill with argon three times. Then $1.0 \mathrm{~mL}$ of freshly distilled quinoline was added and the solution was heated to $220^{\circ} \mathrm{C}$. After $1 \mathrm{~h}$, the reaction mixture was cooled to room temperature. The precipitate was filtered and washed repeatedly with acetone and methanol. The dark green filtrate was concentrated under vacuum. The crude product was purified using a Sephadex LH-20 column and acetone for elution. The pure phthalocyanine was obtained by reverse phase HPLC using a Luna $\mathrm{C}_{18}$ semi-preparative column and water/ acetonitrile as the mobile phase, with a multi-step gradient method. The pure product was collected and vacuum dried at $30^{\circ} \mathrm{C}$ for 2 days to afford a dark bluish green solid $(9.0 \mathrm{mg})$ in $8 \%$ yield based on the amount of 4 used. ${ }^{1} \mathrm{H}$ NMR (DMF- $\left.d_{7}, 400 \mathrm{MHz}\right): \delta 9.37-9.12(\mathrm{~m}, 7 \mathrm{H}$, Ar-H), 8.24-8.17 (m, 7H, Ar-H), 7.71 (d, $J=7.8 \mathrm{~Hz}, 1 \mathrm{H}, \mathrm{Ar}-\mathrm{H}), 7.59$ (d, $J=9.0 \mathrm{~Hz}, 2 \mathrm{H}, \mathrm{Ar}-$ $\mathrm{H}), 7.23(\mathrm{~d}, J=9.0 \mathrm{~Hz}, 2 \mathrm{H}, \mathrm{Ar}-\mathrm{H}), 4.31(\mathrm{~s}, 2 \mathrm{H}, \mathrm{CH}), 4.27(\mathrm{~s}, 2 \mathrm{H}, \mathrm{CH}), 4.21(\mathrm{t}, J=4.7 \mathrm{~Hz}, 2 \mathrm{H}$, $\left.\mathrm{OCH}_{2}\right), 3.86\left(\mathrm{t}, J=4.7 \mathrm{~Hz}, 2 \mathrm{H}, \mathrm{OCH}_{2}\right), 3.70-3.68\left(\mathrm{~m}, 2 \mathrm{H}, \mathrm{OCH}_{2}\right), 3.64-3.62(\mathrm{~m}, 2 \mathrm{H}$, $\left.\mathrm{OCH}_{2}\right) .{ }^{13} \mathrm{C}$ NMR (DMF- $\left.d_{7}, 100 \mathrm{MHz}\right): \delta 155.83,154.38,154.24,154.00,153.88,153.53$, $152.80,152.73,141.97,139.38,139.09,131.31,129.96,128.41,123.39,123.02,120.44$, 120.26, 118.56, 116.65 (Ar-C), 72.59, 70.19, 69.23, $68.90\left(\mathrm{OCH}_{2}\right), 54.22,47.21(\mathrm{CH})$. HRMSESI $\mathrm{m} / \mathrm{z}$ 1095.4212 [M-K] ${ }^{-}$, calcd. for $\left[\mathrm{C}_{46} \mathrm{H}_{48} \mathrm{~B}_{18} \mathrm{CoN}_{8} \mathrm{O}_{4} \mathrm{Zn}\right]^{-}$1095.4231. UV-Vis (acetone): $\lambda_{\max }(\log \varepsilon) 672(5.33), 606(4.53) \mathrm{nm}$.

\subsection{Cobaltacarboranyl-phthalocyanine (7)}

The synthesis of this Pc was similar to that of Pc $\mathbf{6}$ described above and afforded a dark green solid in $1 \%$ yield. ${ }^{1} \mathrm{H}$ NMR (DMF- $\left.d_{7}, 400 \mathrm{MHz}\right): \delta 9.54-9.45(\mathrm{~m}, 7 \mathrm{H}, \mathrm{Ar}-\mathrm{H}), 8.26-8.21(\mathrm{~m}$, 7H, Ar-H), $7.78(\mathrm{~m}, 3 \mathrm{H}, \mathrm{Ar}-\mathrm{H}), 7.27-7.24(\mathrm{~m}, 2 \mathrm{H}, \mathrm{Ar}-\mathrm{H}), 5.05\left(\mathrm{~s}, 2 \mathrm{H}, \mathrm{OCH}_{2}\right), 4.50(\mathrm{~s}, 2 \mathrm{H}$, $\left.\mathrm{CH}_{2}\right), 4.39$ (s, 2H, CH), 4.35 (s, 2H, CH), 4.03-4.02 (m, 2H, $\left.\mathrm{OCH}_{2}\right), 3.95-3.92(\mathrm{~m}, 2 \mathrm{H}$, $\left.\mathrm{OCH}_{2}\right)$. UV-Vis (acetone): $\lambda_{\max }(\log \varepsilon) 682(4.77), 616(4.05) \mathrm{nm}$. 


\subsection{X-ray structures}

The crystal structures of phthalonitriles $\mathbf{2}$ and $\mathbf{3}$ were determined, using data collected at low temperature with graphite-monochromated Mo K $\alpha$ radiation $(k=0.71073 \AA)$ on a Nonius Kappa CCD diffractometer. Details of data collection and refinement are given in Table 1. The $\mathrm{H}$ atoms for both structures were visible in difference maps, and were placed in calculated positions, except for the phenolic $\mathrm{H}$ atom of phthalonitrile (2), which was refined. Friedel equivalents were merged for refinement of the polar structure of $\mathbf{2}$.

\section{Supplementary Material}

Refer to Web version on PubMed Central for supplementary material.

\section{Acknowledgments}

The authors acknowledge the National Institutes of Health (grant CA098902) for partially supporting the work described.

\section{References}

[1]. Fabris C, Jori G, Giuntini F, Roncucci G. J. Photochem. Photobiol. B: Biol 2001;64:1-7.

[2]. Giuntini F, Raoul Y, Dei D, Municchi M, Chiti G, Fabris C, Colautti P, Jori G, Roncucci G. Tetrahedron Lett 2005;46:2979-2982.

[3]. Friso E, Roncucci G, Dei D, Soncin M, Fabris C, Chiti G, Colautti P, Esposito J, Nardo LD, Rossi CR, Nitti D, Giuntini F, Borsetto L, Jori G. Photochem. Photobiol. Sci 2006;1:39-50. [PubMed: 16395426]

[4]. Tsaryova O, Semioshkin A, Wohrle D, Bregadze VI, Porphyr J. Phthalocyan 2005;9:268-274.

[5]. Barth RF, Coderre JA, Vicente MGH, Blue TE. Clin. Cancer Res 2005;11:3987-4002. [PubMed: 15930333]

[6]. Dougherty TJ, Gomer CJ, Henderson BW, Jori G, Kessel D, Korbelik M, Moan J, Peng Q. J. Natl. Cancer Inst 1998;90:889-905. [PubMed: 9637138]

[7]. Luguya R, Jenson TJ, Smith KM, Vicente MGH. Bioorg. Med. Chem 2006;14:5890-5897. [PubMed: 16753299]

[8]. Hao E, Friso E, Miotto G, Jori G, Soncin M, Fabris C, Sibrian-Vazquez M, Vicente MGH. Org. Biomol. Chem 2008;6:3732-3740. [PubMed: 18843403]

[9]. Gottumukkala V, Ongayi O, Baker DG, Lomax LG, Vicente MGH. Bioorg. Med. Chem 2006;14:1871-1879. [PubMed: 16298134]

[10]. Li H, Fronczek FR, Vicente MGH. Tetrahedron Lett 2008;49:4828-4830.

[11]. Kennedy JC, Marcus SL, Pottier RH. J. Clin. Laser Med. Surg 1996;14:289-304. [PubMed: 9612195]

[12]. Detty MR, Gibson SL, Wagner SJ. J. Med. Chem 2004;47:3897-3915. [PubMed: 15267226]

[13]. Teixidor F, Pedrajas J, Rojo I, Vinas C, Kivekas R, Sillanpaa R, Sivaev I, Bregadze V, Sjoberg S. Organometallics 2003;22:3414-3423.

[14]. Hao E, Vicente MGH. Chem. Commun 2005:1306-1308.

[15]. Hao E, Jensen TJ, Courtney BH, Vicente MGH. Bioconjugate Chem 2005;16:1495-1502.

[16]. Hao E, Sibrian-Vazquez M, Serem W, Garno JC, Fronczek FR, Vicente MGH. Chem. Eur. J 2007;13:9035-9042.

[17]. Fery-Forgues S, Lavabre D. J. Chem. Educ 1999;76:1260-1264.

[18]. Li H, Jensen TJ, Fronczek FR, Vicente MGH. J. Med. Chem 2008;51:502-511. [PubMed: 18189349] 
a

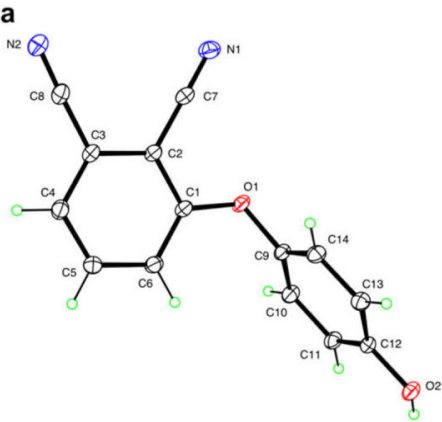

b

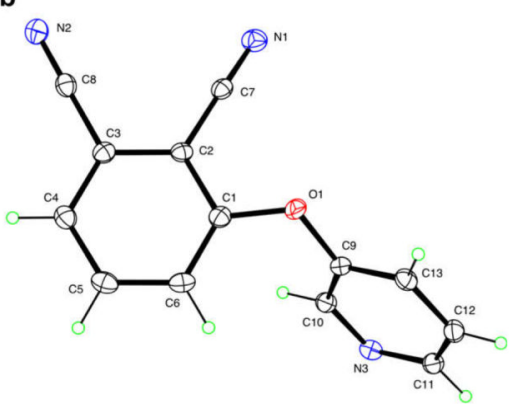

Fig. 1.

Molecular structures of phthalonitriles (a) 2 and (b) 3 . 


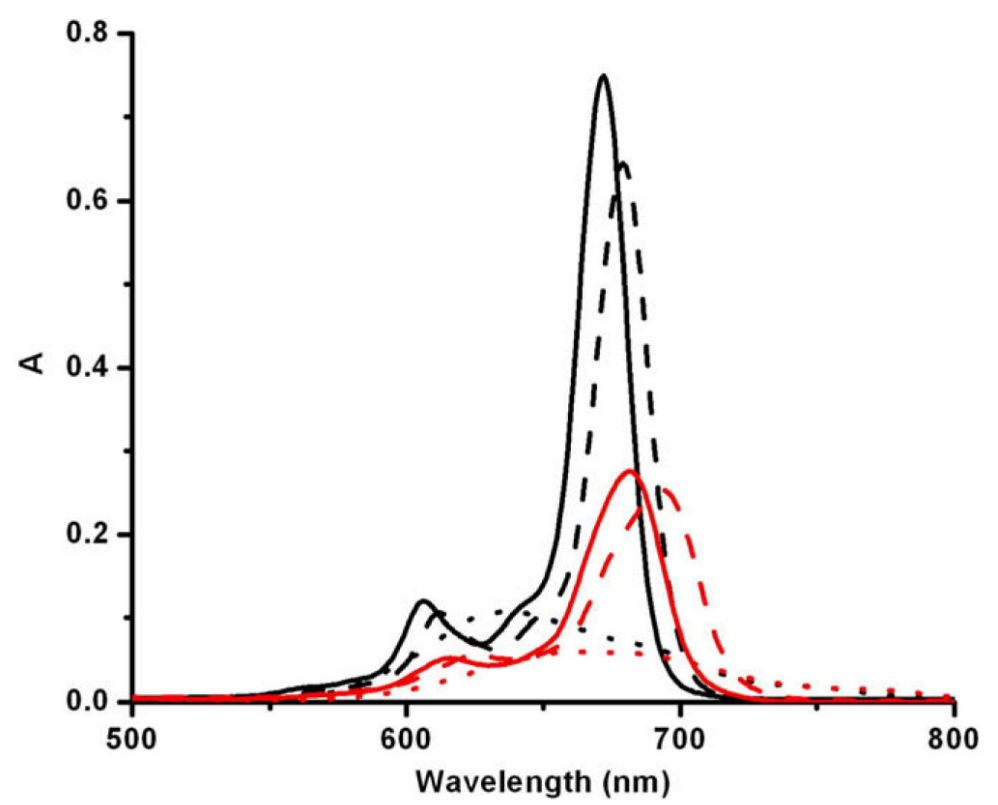

Fig. 2.

UV-Vis spectra of Pcs 6 (black) and 7 (red) at $4.5 \mu \mathrm{M}$ concentration in acetone (full line), DMSO (dash line), and HEPES pH 7.4 (dot line). (For interpretation of the references to colour in this figure legend, the reader is referred to the web version of this article.) 


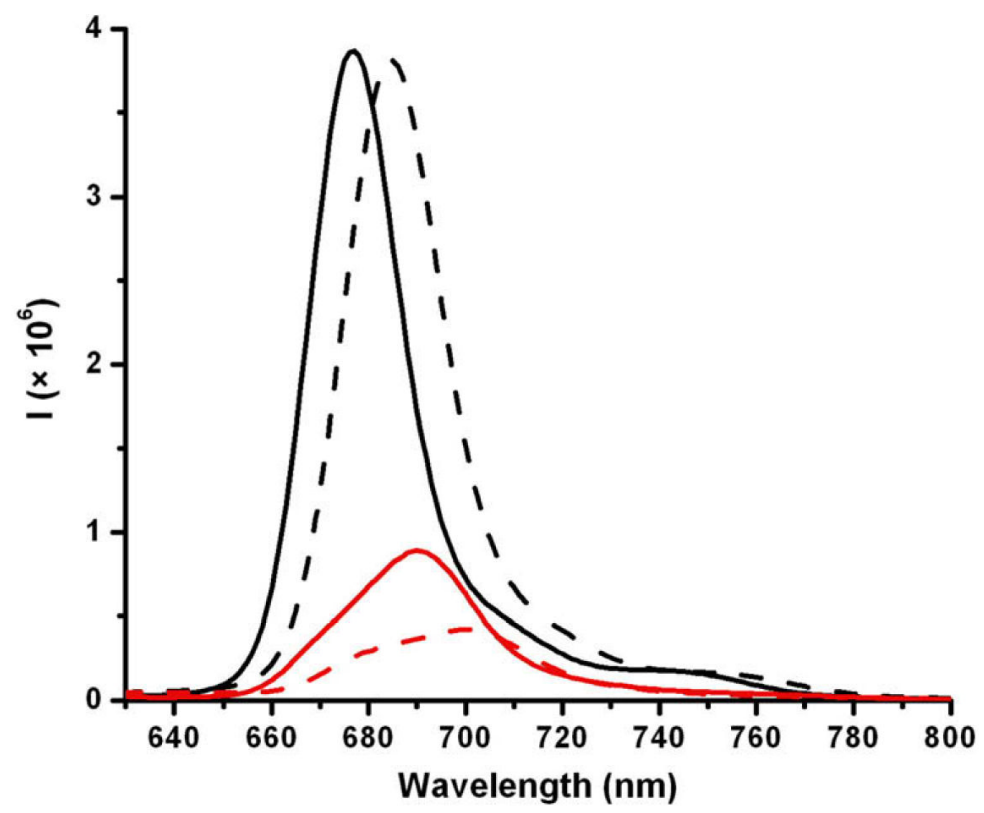

Fig. 3.

Emission spectra of Pcs 6 (black) and 7 (red) at $0.4 \mu \mathrm{M}$ concentration in acetone (full line) and DMSO (dash line). (For interpretation of the references to colour in this figure legend, the reader is referred to the web version of this article.) 


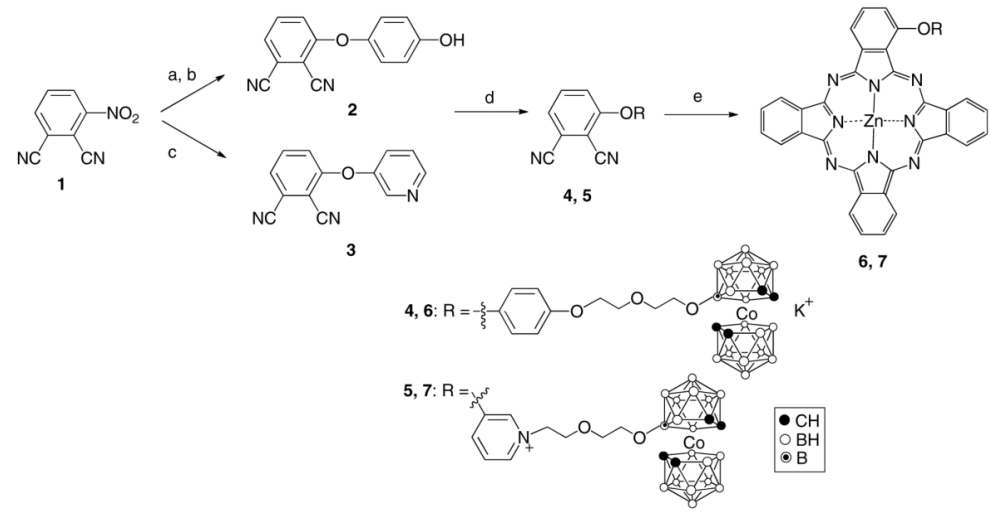

Scheme 1.

Conditions: (a) 4-methoxyphenol, $\mathrm{K}_{2} \mathrm{CO}_{3}$, DMF, $90{ }^{\circ} \mathrm{C}$ (83\%); (b) $\mathrm{BBr}_{3}, \mathrm{CH}_{2} \mathrm{Cl}_{2},-80{ }^{\circ} \mathrm{C}$ (40\%); (c) 3-hydroxypyridine, $\mathrm{K}_{2} \mathrm{CO}_{3}$, DMF, $90{ }^{\circ} \mathrm{C}$ (74\%); (d) 3,3'-Co(8- $\mathrm{C}_{4} \mathrm{H}_{8} \mathrm{O}_{2}-1$,2$\left.\mathrm{C}_{2} \mathrm{~B}_{9} \mathrm{H}_{10}\right)\left(1^{\prime}, 2^{\prime}-\mathrm{C}_{2} \mathrm{~B}_{9} \mathrm{H}_{10}\right), \mathrm{K}_{2} \mathrm{CO}_{3}, 50{ }^{\circ} \mathrm{C}, 24 \mathrm{~h}(94 \%)$; (e) 30 equiv. phthalonitrile, $\mathrm{Zn}$ $(\mathrm{OAc})_{2}$, quinoline, $220^{\circ} \mathrm{C}, 1 \mathrm{~h}(1-8 \%)$. 


\section{Table 1}

Crystal data and structure refinement.

\begin{tabular}{|c|c|c|}
\hline & 2 & 3 \\
\hline Formula & $\mathrm{C}_{14} \mathrm{H}_{8} \mathrm{~N}_{2} \mathrm{O}_{2}$ & $\mathrm{C}_{13} \mathrm{H}_{7} \mathrm{~N}_{3} \mathrm{O}$ \\
\hline CCDC deposition no. & CCDC 699696 & CCDC 699697 \\
\hline Formula weight & 236.22 & 221.22 \\
\hline Crystal system & Orthorhombic & Monoclinic \\
\hline Space group & $P n a 2_{1}$ & $P 2_{1} / n$ \\
\hline \multicolumn{3}{|l|}{ Cell dimensions } \\
\hline$a(\AA)$ & $17.586(2)$ & $9.151(2)$ \\
\hline$b(\AA)$ & $11.7388(15)$ & $10.401(2)$ \\
\hline$c(\AA)$ & $5.4751(5)$ & $11.457(2)$ \\
\hline$\beta\left(^{\circ}\right)$ & 90 & $108.690(10)$ \\
\hline$V\left(\AA^{3}\right)$ & $1130.3(2)$ & $1033.0(4)$ \\
\hline Temperature (K) & 90 & 90 \\
\hline$Z$ & 4 & 4 \\
\hline Crystal size & $0.17 \times 0.22 \times 0.25$ & $0.17 \times 0.23 \times 0.25$ \\
\hline$\mu\left(\mathrm{mm}^{-1}\right)$ & 0.096 & 0.095 \\
\hline$\theta_{\max }\left({ }^{\circ}\right)$ & 35.0 & 30.0 \\
\hline Data collected & 21256 & 13500 \\
\hline Independent data & 2677 & 3018 \\
\hline Observed $(I>2 \sigma(I))$ & 2361 & 2311 \\
\hline$\left[R_{(\mathrm{int})}\right]$ & 0.022 & 0.028 \\
\hline$R$ & 0.037 & 0.040 \\
\hline$w R_{2}[I>2 \sigma(I)]$ & 0.096 & 0.097 \\
\hline Data/parameter & $2677 / 166$ & $3018 / 155$ \\
\hline Residual density (e $\AA^{-3}$ ) & $0.42,-0.24$ & $0.33,-0.22$ \\
\hline
\end{tabular}


